Journal of Elemantary School (JOES)

Volume 1, Nomor 1, Juni 2018

e-ISSN : 2615-1448

p-ISSN : 2620-7338

DOI : https://doi.org/10.31539/joes.v1i1.222

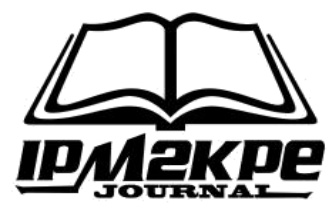

\title{
UPAYA MENINGKATKAN HASIL BELAJAR MATEMATIKA BANGUN RUANG DENGAN MENGGUNAKAN MODEL PEMBELAJARAN KOOPERATIF TIPE JIGSAW
}

\author{
Linda Ismayani \\ SD Negeri 46 Lubuklinggau \\ lindaismayani2018@gmail.com
}

\begin{abstract}
ABSTRAK
Tujuan penelitian ini untuk mengetahui adanya peningkatan hasil belajar matematika materi bangun ruang melalui model pembelajaran Kooperatif tipe Jigsaw pada siswa kelas IV SD Negeri 46 Lubuklinggau Tahun Pelajaran 2016/2017. Subyek dalam penelitian ini adalah siswa Kelas IV SD Negeri 46 Lubuklinggau yang berjumlah 22 siswa. Penelitian ini akan dilaksanakan pada semester genap di kelas Tahun Ajaran 2016/2017 pada bulan April sampai dengan Mei Tahun 2017. Penelitian tindakan kelas ini telah dikatakan tuntas dengan dibuktikannya peningkatan hasil belajar Matematika materi bangun ruang Model pembelajaran Kooperatif Tipe Jigsaw semester genap tahun ajaran 2016/2017. Hasil Ketuntasan belajar meningkat dari pra siklus, siklus I, ke siklus II yaitu masing-masing 41\%, 73\%, dan 86\%. Pada siklus II ketuntasan belajar siswa secara klasikal telah tercapai dan mengalami peningkatan yang sangat baik. Selain itu nilai rata-rata hasil observasi aktifitas belajar siswa Siklus II mencapai 85,45 dalam katagori sangat aktif. Simpulan terbukti bahwa model pembelajaran Kooperatif Tipe Jigsaw dapat meningkatkan hasil belajar Matematika siswa kelas IV SD Negeri 46 Lubuklinggau.
\end{abstract}

Kata Kunci: Hasil Belajar, Model Kooperatif Tipe Jigsaw

\section{ABSTRACT}

The purpose of this study to determine the improvement of learning outcomes mathematics building materials through the model of cooperative learning type Jigsaw on fourth grade students SD Negeri 46 Lubuklinggau Lesson 2016/2017. The subjects in this study were students of Class IV SD Negeri 46 Lubuklinggau which amounted to 22 students. This study will be conducted on even semesters in the 2016/2017 School Year classes from April to May 2017. This classroom action research has been said to be complete with the proven improvement of learning outcomes Mathematics of building materials Jigsaw Type Co-operative learning model of the academic year 2016 / 2017. Learning mastery increased from pre cycle, cycle I, to cycle II that is $41 \%, 73 \%$, and $86 \%$ respectively. In the second cycle of student learning completeness has been achieved in classical and experienced a very good improvement. Besides, the average value of observation result of student learning activity Cycle II reach 85.45 in very active category

Keyword: Learning Outcomes, Jigsaw Type Co-operative Model 


\section{PENDAHULUAN}

Pendidikan merupakan suatu usaha sadar untuk menyiapkan peserta didik melalui kegiatan bimbingan, pengajaran, dan latihan. Hal ini sesuai dengan tujuan pendidikan nasional yaitu mencerdaskan kehidupan bangsa dalam segala aspek kehidupan yang cukup keterampilan, nilai dan sikap. Proses pembelajaran merupakan suatu proses yang mengandung serangkaian kegiatan antara guru dan siswa. Dalam interaksi timbal balik yang berlangsung dalam situasi yang edukatif, untuk mencapai tujuan pembelajaran yang telah diterapkan. Guru sebagai pendidik bertugas membelajarkan siswa dan mentransfer pengetahuan, keterampilan serta sikap. Sedangkan tugas siswa adalah belajar.

Keberhasilan siswa dalam belajar di pengaruhi oleh dari dalam diri siswa dan dari luar diri siswa. Faktor dari dalam meliputi : motivasi, minat, perhatian, dan aktifitas belajar. Sedangkan faktor dari luar mencakup lingkungan, suasana belajar, guru, sumber belajar dan metode pembelajaran yang digunakan. Kurangnya kemampuan siswa terhadap pelajaran Matematika akan menghambat proses pembelajaran. Rendahnya kemampuan siswa terhadap suatu pelajaran belum tentu sumber kesalahannya terletak pada diri siswa. Keterampilan guru menyampaikan materi ajar dan metode pembelajaran yang kurang tepat dan kurang memadai dapat menyebabkan kelas menjadi tidak menarik dan cenderung membosankan siswa.

Berdasarkan hasil penelitian pada kelas IV SD Negeri 46 Lubuklinggau pada proses pembelajaran Matematika ternyata guru hanya menggunakan metode ceramah, dimana siswa hanya menjadi pendengar, tanpa adanya umpan balik. Untuk melibatkan siswa secara langsung sehingga siswa merasa bosan dan tidak memperhatikan materi yang disampaikan guru. Hal ini mengakibatkan hasil belajar dan kemampuan siswa terhadap materi pelajaran Matematika khususnya materi tentang Bangun Ruang, siswa masih kurang mampu. Untuk itu perlunya perubahan dalam strategi pembelajaran tentang metode pembelajaran yang diterapkan oleh guru yaitu melalui penggunaa modal pembelajaran Kooperatif Tipe Jigsaw di mana siswa melatih keterampilan dan kemampuan berpikir untuk meningkatkan hasil belajarnya, meningigat pentingnya kemampuan siswa dalam pembelajaran Matematika bagi kehidupan pribadi, masyarakat dan negara, maka peneliti mengangkat judul untuk meningkatkan kualitas belajar bagi siswa, guru dan sekolah.

Salah satu model yang dapat digunakan dalam proses pembelajaran Matematika adalah penggunaan model pembelajaran kooperatif tipe jigsaw yang diharapkan soal-soal dapat dipecahkan dan dicari solusinya oleh anak-anak dalam proses pembelajaran Matematika (Slavin, 2009). Dengan demikian diharapkan agar siswa mampu berpikir kreatif, kritis dan analitis dalam mencari dan menemukan sendiri jawaban dari suatu masalah serta mengerti, memahami dan menerapkan konsep Matematika dalam kehidupan sehari-hari. Berdasarkan permasalahan di atas, 
peneliti tertarik untuk melakukan penelitian tindakan kelas (PTK) dengan menerapkan model pembelajaran kooperatif tipe jigsaw.

\section{METODE PENELITIAN}

Penelitian ini merupakan penelitian tindakan kelas (class action research), karena penelitian dilakukan untuk memecahkan masalah pembelajaran di kelas. Menurut Zainal (2006) penelitian tindakan kelas atau PTK memiliki peranan yang sangat penting dan strategis untuk meningkatkan mutu pembelajaran apabila diimplementasikan dengan baik dan benar. Menurut Arikunto (2011) penelitian tindakan kelas merupakan kegiatan kolaborasi peneliti (guru) yang melibatkan peserta didik dalam proses pembelajaran. Penelitan ini dilaksanakan di Kelas IV SD Negeri 46 Lubuklinggau dari bulan April s/d Mei 2017 Tahun Pelajaran 2016/2017. Subjek dalam penelitian ini adalah peserta didik kelas Kelas IV SD Negeri 46 Lubuklinggau. Adapun jumlah peserta didiknya adalah 22, terdiri dari 11 siswa laki-laki dan 11 siswa perempuan. Selama pelaksanaan penilaian, untuk mengamati proses pembelajaran dan membantu pengumpulan data peneliti dibantu oleh teman sejawat Ibu Rahmawarni, S.Pd.SD guru kelas senior dari SD Negeri 46 Lubuklinggau Kota Lubuklinggau.

Indikator keberhasilan penelitian tindakan kelas IV ini adalah secara keseluruhan peserta didik tidak mengalami kesulitan dalam menyelesaikan soal tes yang diberikan pada setiap akhir tindakan. Hal ini ditunjukan dengan hasil belajar peserta didik memperoleh KKM diatas 70 dengan persentase di atas nilai rata-rata sebanyak $\geq 85 \%$. Penelitian ini dilaksanakan dalam dua (2) siklus yang masingmasing siklus terdiri dari 2 kali pertemuan. Setiap siklus dilakukan langkah-langakah kegiatan mulai dari perencanaan (planning), tindakan (action), observasi (observation) dan diakhiri dengan refleksi (reflection).

Tahap-tahap penelitian yang dilakukan antara lain mencakup tahap perencanaan dan tahap pelaksanaan kegiatan penelitian. Pertama Tahap Perencanaan meliputi; a) tahap awal. Melakukan pertemuan awal dengan teman sejawat SD Negeri 46 Lubuklinggau untuk membahas tentang rencana penelitian yang akan dilaksanakan. Menyiapkan sumber data. Menentukan kelompok belajar yang terdiri dari 4-5 orang dengan pembagian yang rata pada setiap kelompok sesuai kemampuan peserta didik, b) menetapkan dan merumuskan rancangan tindakan Pada tahap ini, kegiatan yang dilakukan adalah (menentukan tujuan pembelajaran, membuat LKS, menyiapkan lembar observasi, menyiapkan kisi-kisi soal, membuat soal tes); kedua Tahap Pelaksanaan Tindakan. Pada tahap ini peneliti melaksanakan pembelajaran Matematika dengan menggunakan model belajar kooperatif tipe Jigsaw yaitu sebagai berikut: a) kegiatan pendahuluan (guru membuka pelajaran dengan salam dan mengabsen kehadiran peserta didik, guru menuliskan pokok bahasan yang akan 
dipelajari, guru menyampaikan tujuan pembelajaran, guru memberikan apersepsi dan motivasi, guru menjelaskan kepada peserta didik tentang model belajar kooperatif tipe Jigsaw yang akan dilaksanakan pada hari itu, guru menyiapkan alat berupa spidol dan penghapus serta gambar peraga bangun ruang); keetiga Kegiatan Inti. Langkah-langkah pokok pelaksanaan pembelajaran kooperatif tipe Jigsaw meliputi (siswa dikelompokkan ke dalam 4-5 anggota tim, tiap orang dalam tim diberi bagian materi yang berbeda, tiap orang dalam tim diberi bagian materi yang ditugaskan) anggota dari tim yang berbeda yang telah mempelajari bagian/sub bab yang sama bertemu dalam kelompok baru (kelompok ahli) untuk mendiskusikan sub bab mereka. Setelah selesai diskusi sebagai tim ahli tiap anggota kembali ke kelompok asal dan bergantian mengajar teman satu tim mereka tentang sub bab yang mereka kuasai dan tiap anggota lainnya mendengarkan dengan sungguh-sungguh. Tiap tim ahli mempresentasikan hasil diskusi, guru memberi evaluasi, dam Penutup

Prosedur yang digunakan untuk pengumpulan data yang diperlukan dalam penelitian ini adalah: Tes hasil belajar adalah serentetan pertanyaan atau latihan serta alat lain yang digunakan untuk mengukur keterampilan, pengetahuan, kemampuan atau bakat yang dimiliki oleh individu. Dalam menggunakan metode tes, peneliti menggunakan soal-soal tes yang berhubungan dengan materi bangun ruang sebanyak 5 soal essay. Observasi adalah kegiatan pengamatan (pengambilan data) untuk melihat seberapa jauh efek tindakan telah mencapai sasaran. Kegiatan yang diamati meliputi aktivitas peneliti sebagai pengajar dan aktivitas peserta didik dalam pembelajaran dengan menggunakan lembar observasi. Selama kegiatan berlangsung dilakukan pengamatan dengan menggunakan lembar observasi terdiri dari lima indikator yang masing-masing terdiri dari dua deskriptor.

Untuk menganalisis tingkat keberhasilan atau persentase keberhasilan peserta didik setelah proses belajar mengajar setiap putarannya dilakukan dengan cara memberikan evaluasi berupa soal tes tertulis pada setiap akhir putaran. Analisis ini dihitung dengan menggunakan statistik sederhana yaitu untuk menilai ulangan atau tes formatif. Peneliti melakukan penjumlahan nilai yang diperoleh peserta didik, yang selanjutnya dibagi dengan jumlah peserta didik yang ada di kelas tersebut sehingga diperoleh rata-rata tes formatif dapat dirumuskan:

$$
\bar{X}=\frac{\sum X}{\sum N}
$$

Dengan: $\quad=$ Nilai rata-rata

$\Sigma \mathrm{X}=$ Jumlah semua nilai peserta didik

$\Sigma \mathrm{N} \quad=$ Jumlah peserta didik (Daryanto, 2011) 
Untuk ketuntasan belajar. Ada dua kategori ketuntasan belajar yaitu secara perorangan dan secara klasikal. Berdasarkan petunjuk pelaksanaan belajar mengajar di kelas IV SD Negeri 46 Lubuklinggau, yaitu seorang peserta didik telah tuntas belajar bila telah mencapai nilai 72 , dan kelas disebut tuntas belajar bila di kelas tersebut terdapat $85 \%$ yang telah mencapai daya serap lebih dari atau sama dengan $85 \%$. Untuk menghitung persentase ketuntasan belajar digunakan rumus sebagai berikut:

$$
P=\frac{\sum \text { Siswa.yang.tuntas.belajar }}{\sum \text { Siswa }} \times 100 \%
$$

(Alam dan Hermana, 2008)

Lembar Observasi Aktivitas Siswa. Analisis data lembar observasi aktivitas siswa dalam kegiatan belajar mengajar, dirumuskan sebagai berikut:

$$
\begin{array}{ll}
\mathrm{NP}=\mathrm{R} /(\mathrm{SM}) \times 100 \% \\
\mathrm{NP}=\mathrm{R} /(\mathrm{SM}) \times 100 \% \\
\text { Keterangan : } \\
\mathrm{NP}=\quad \text { nilai persen yang dicari atau diharapkan } \\
\mathrm{R}=\quad \text { skor mentah yang diperoleh } \\
\mathrm{SM}= & \text { skor maksimum } \\
100= & \text { bilangan tetap (Purwanto, 2001) }
\end{array}
$$

Persentase tersebut dapat mewakili aktivitas siswa selama berlangsungnya kegiatan pembelajaran Matematika bangun ruang menggunakan model pembelajaran Kooperatif tipe Jigsaw. Kategori persentase observasi keaktifan siswa menurut Arikunto (2002) yaitu:

\section{Keterangan :}

80 - 100 sangat aktif

$66-79$ Aktif

56 - 65 cukup aktif

40 - 55 kurang aktif

$<40 \quad$ sangat kurang aktif

\section{HASIL PENELITIAN}

\section{Deskripsi Kondisi Awal}

Sebelum dilakukan tindakan, proses belajar mengajar untuk mata pelajaran Matematika masih terfokus kepada guru dan kurang terfokus pada siswa. Akibatnya kegiatan belajar mengajar lebih ditekankan pada pengajaran dari pada pembelajaran 
Kondisi tersebut menjadikan aktifitas belajar siswa kelas IV cenderung rendah dan monoton, ditandai dengan siswa lebih senang diceramahi, siswa sedikit sekali yang mau bertanya, sedikit siswa yang mampu menjawab pertanyaan, dan contoh-contoh materi pelajaran yang diberikan guru masih kurang terkait dengan lingkungan kehidupan siswa sehari-hari. Hal inilah yang menyebabkan nilai rata-rata hasil belajar Matematika pada materi bangun ruang menjadi rendah yaitu 58,18 seperti tertera pada tabel di bawah ini.

Tabel 1

Data Hasil Belajar Kondisi Awal

\begin{tabular}{llllll}
\hline No & Kriteria & $\begin{array}{l}\text { Rentang } \\
\text { Nilai }\end{array}$ & Jumlah & Persentase & Rata-Rata \\
\hline 1 & Belum Mencapai KKM & $40-69$ & 13 & $41 \%$ & 58,18 \\
\cline { 1 - 4 } 2 & Sudah Mencapai KKM & $70-100$ & 9 & $59 \%$ & \\
\hline
\end{tabular}

Nilai tertinggi dan terendah hasil belajar pada kondisi awal juga dapat penulis paparkan pada tabel di bawah ini.

Table 2

Nilai Tertinggi dan Terendah Kondisi Awal

\begin{tabular}{lll}
\hline No & Keterangan & Nilai \\
\hline 1 & Nilai Tertinggi & 80 \\
\hline 2 & Nilai Terendah & 40 \\
\hline 4 & Nilai Rata-rata & 58,18 \\
\hline
\end{tabular}

\section{Deskripsi Data Hasil Penelitian Siklus I}

Pada Siklus I ini, Guru menyusun berbagai kegiatan, pertama Perencanaan Tindakan. Berdasarkan hasil refleksi awal, peneliti bersama teman sejawat menyusun rencana tindakan untuk memecahkan masalah yang ditentukan dalam refleksi awal. Perencanaan ini mencakup permohonan izin kepada Kepala Sekolah, menyusun rencana pelaksanaan pembelajaran (RPP) materi bangun ruang, memilih model pembelajaran kooperatif tipe Jigsaw, membuat dan merancang lembar observasi aktifitas siswa, menyiapkan lembar diskusi siswa, menyiapkan lembar evaluasi, menyiapkan kunci jawaban evaluasi. Kedua Pelaksanaan Tindakan. Pelaksanaan siklus I terdiri dari 2 kali pertemuan, masing-masing pertemuan 3 x 35 menit. Dalam laporan ini akan diuraikan pelaksanaan pembelajaran tindakan siklus I yang dilaksanakan pada tanggal 10 April 2017 untuk pertemuan pertama dan tanggal 13 April 2017 untuk pertemuan kedua. 
Berikut hasi belajar setelah diberikan tindakan pada siklus I secara lengkap dapat penulis paparkan pada tabel di bawah ini.

Tabel 3

Data Hasil Belajar Siklus I

\begin{tabular}{l|ll|l|l|l}
\hline No & Kriteria & $\begin{array}{l}\text { Rentang } \\
\text { Nilai }\end{array}$ & Jumlah & persentase & Rata-Rata \\
\hline 1 & $\begin{array}{l}\text { Belum Mencapai } \\
\text { KKM }\end{array}$ & $0-71$ & 6 & $27 \%$ & 75,45 \\
\hline 2 & $\begin{array}{l}\text { Sudah Mencapai } \\
\text { KKM }\end{array}$ & $72-100$ & 16 & $73 \%$ & \\
\hline
\end{tabular}

Table 4

Nilai Tertinggi dan Terendah Pada Siklus I

\begin{tabular}{ccc}
\hline No & Keterangan & Nilai \\
\hline 1 & Nilai Tertinggi & 100 \\
\hline 2 & Nilai Terendah & 40 \\
\hline 3 & Nilai Rata-rata & 75,45 \\
\hline
\end{tabular}

Ketiga Pengamatan/ Observasi. Pada saat pembelajaran berlangsung dilakukan pengamatan terhadap aktifitas belajar siswa dengan menggunakan lembar observasi yang telah dipersiapkan untuk mengamati aktivitas yang dilakukan oleh siswa. Aktivitas siswa diukur dengan berpedoman pada deskriptor yang ada pada lembar observasi. Keaktivan siswa dalam proses pembelajaran menggunakan model pembelajaran Kooperatif tipe Jigsaw pada Siklus I dapat dilihat pada tabel observasi berikut.

Tabel 5

Rekapitulasi Aktifitas Siswa Pada Siklus I

\begin{tabular}{|c|c|c|c|c|c|c|}
\hline No & Deskriptor & & Indikator & $\begin{array}{l}\text { Nilai } \\
\text { indikator }\end{array}$ & $\begin{array}{l}\text { Rata- } \\
\text { rata } \\
\text { Indika } \\
\text { tor }\end{array}$ & $\begin{array}{l}\text { Rata-rata } \\
\text { Deskript } \\
\text { or }\end{array}$ \\
\hline \multirow{2}{*}{1} & \multirow{2}{*}{$\begin{array}{l}\text { Tanggung } \\
\text { Individu }\end{array}$} & \multirow[t]{2}{*}{ Jawab } & $\begin{array}{l}\text { Mengerjakan tugas } \\
\text { kelompok }\end{array}$ & 18 & 81,82 & \multirow{2}{*}{70,45} \\
\hline & & & $\begin{array}{l}\text { Hasil tugas yang } \\
\text { diberikan }\end{array}$ & 13 & 59,09 & \\
\hline \multirow[b]{2}{*}{2} & \multirow[b]{2}{*}{$\begin{array}{l}\text { Tanggung } \\
\text { kelompok }\end{array}$} & \multirow[b]{2}{*}{ jawab } & $\begin{array}{l}\text { Menyelesaikan tugas } \\
\text { tepat waktu }\end{array}$ & 11 & 50,00 & \multirow[b]{2}{*}{56,82} \\
\hline & & & $\begin{array}{l}\text { Kelompok dapat } \\
\text { menyelesaikan } \\
\text { tugasnya dengan benar }\end{array}$ & 14 & 63,64 & \\
\hline
\end{tabular}




\begin{tabular}{|c|c|c|c|c|c|}
\hline \multirow[b]{2}{*}{3} & \multirow[b]{2}{*}{ Kerja Sama } & $\begin{array}{l}\text { Bekerja sama dalam } \\
\text { menyelesaikan tugas }\end{array}$ & 14 & 63,64 & \multirow[b]{2}{*}{52,27} \\
\hline & & $\begin{array}{l}\text { Mengemukakan } \\
\text { pendapat dalam } \\
\text { memecahkan masalah }\end{array}$ & 9 & 40,91 & \\
\hline \multirow[t]{2}{*}{4} & \multirow[t]{2}{*}{ Pembagian Tugas } & $\begin{array}{l}\text { Mendapatkan tugasnya } \\
\text { secara merata }\end{array}$ & 22 & 100 & \multirow[t]{2}{*}{88,64} \\
\hline & & Mengerjakan tugas & 17 & 77,27 & \\
\hline \multirow{4}{*}{5} & \multirow{2}{*}{ Kepemimpinan } & $\begin{array}{lr}\text { Mampu } & \text { mengajak } \\
\text { anggota } & \text { kelompoknya } \\
\text { kompak } & \end{array}$ & 15 & 68,18 & \multirow{2}{*}{68,19} \\
\hline & & $\begin{array}{l}\text { Mengarahkan anggota } \\
\text { kelompoknya }\end{array}$ & 15 & 68,18 & \\
\hline & $\begin{array}{l}\text { Rata-Rata } \\
\text { Keseluruhan }\end{array}$ & & & & 67,27 \\
\hline & Katagori & & & & Aktif \\
\hline
\end{tabular}

Dari tabel tersebut terlihat rata-rata keaktifan siswa 67,27\%, apabila merujuk pada tabel keaktifan siswa dalam materi bangun ruang kubus, maka termasuk dalam kategori aktif.

Keempat Refleksi tindakan pada siklus I ini lebih difokuskan pada masalah yang muncul selama tindakan. Berdasarkan deskripsi data siklus I, maka dalam pembelajaran ditemukan permasalahan sebagai berikut: Hasil tes menunjukkan bahwa masih ada $27 \%$ siswa yang belum tuntas belajarnya. Ketuntasan belajar kelas hanya $73 \%$ sehingga ketuntasan belajar belum tercapai. Kemudian pada aktivitas pembelajaran tampak bahwa pembelajaran dengan menggunakan model pembelajaran Kooperatif tipe Jigsaw belum berjalan secara efektif. Hal ini karena model pembelajaran kooperatif tipe Jigsaw ini merupakan hal yang baru sehingga siswa belum bisa mengikuti proses pembelajaran dengan baik karena siswa belum terbiasa dengan model pembelajaran yang digunakan. Masih tedapat siswa yang tidak melaksanakan dengan baik tanggung jawabnya di kelompok, di diskusi kelompok ahli masih terlihat siswa yang hanya diam saja dan mengandalkan teman yang pintar.

\section{Deskripsi Data Hasil Penelitian Siklus II}

Sama halnya pada siklus I, pada Siklus ke-II ini, Guru menyusun berbagai kegiatan berupa, pertama Perencanaan Tindakan. Berdasarkan hasil refleksi siklus I, peneliti bersama teman sejawat menyusun rencana tindakan untuk memecahkan masalah yang ditentukan dalam refleksi siklus I. Menyusun rencana pelaksanaan pembelajaran (RPP) siklus II materi bangun ruang balok, menggunakan model pembelajaran kooperatif tipe Jigsaw, membuat dan merancang lembar observasi aktifitas siswa, menyiapkan lembar diskusi siswa, menyiapkan lembar evaluasi, menyiapkan kunci jawaban evaluasi. Kedua Pelaksanaan Tindakan. Pelaksanaan siklus II terdiri dari 2 kali pertemuan, masing-masing pertemuan 3 x 35 menit. Dalam laporan ini akan diuraikan pelaksanaan pembelajaran tindakan siklus II yang dilaksanakan pada tanggal 17 April 2017 untuk pertemuan pertama dan tanggal 20 April 2017 untuk pertemuan kedua. Materi bangun ruang balok 
Berikut hasi belajar setelah diberikan tindakan pada siklus II secara lengkap dapat penulis paparkan pada tabel di bawah ini.

Tabel 6

Data Hasil Belajar Siklus II

\begin{tabular}{llllll}
\hline No & Kriteria & $\begin{array}{l}\text { Rentang } \\
\text { Nilai }\end{array}$ & Jumlah & persentase & Rata-Rata \\
\hline 1 & $\begin{array}{l}\text { Belum Mencapai } \\
\text { KKM }\end{array}$ & $0-71$ & 3 & $86 \%$ & 86,36 \\
\hline 2 & $\begin{array}{l}\text { Sudah Mencapai } \\
\text { KKM }\end{array}$ & $72-100$ & 19 & $14 \%$ & \\
\hline
\end{tabular}

Tabel 7

Nilai Tertinggi dan Terendah Pada Siklus II

\begin{tabular}{ccc}
\hline No & Keterangan & Nilai \\
\hline 1 & Nilai Tertinggi & 100 \\
\hline 2 & Nilai Terendah & 60 \\
\hline 3 & Nilai Rata-rata & 86,36
\end{tabular}

Ketiga Pengamatan/ Observasi. Pada saat pembelajaran berlangsung dilakukan pengamatan terhadap aktifitas belajar siswa dengan menggunakan lembar observasi yang telah dipersiapkan untuk mengamati aktivitas yang dilakukan oleh siswa. Aktivitas siswa diukur dengan ber $\neg$ pedoman pada deskriptor yang ada pada lembar observasi. Keaktivan siswa dalam proses pembelajaran menggunakan model pembelajaran Kooperatif tipe Jigsaw pada Siklus II dapat dilihat pada tabel observasi berikut.

Tabel 8

Rekapitulasi Hasil Observasi Aktifitas Siswa Siklus II

\begin{tabular}{|c|c|c|c|c|c|c|}
\hline No & Deskriptor & & Indikator & $\begin{array}{l}\text { Nilai } \\
\text { indikator }\end{array}$ & $\begin{array}{l}\text { Rata- } \\
\text { rata } \\
\text { Indika } \\
\text { tor }\end{array}$ & $\begin{array}{l}\text { Rata-rata } \\
\text { Deskript } \\
\text { or }\end{array}$ \\
\hline \multirow{2}{*}{1} & \multirow{2}{*}{$\begin{array}{l}\text { Tanggung } \\
\text { Individu }\end{array}$} & \multirow[t]{2}{*}{ Jawab } & $\begin{array}{l}\text { Mengerjakan tugas } \\
\text { kelompok }\end{array}$ & 20 & 90,91 & \multirow{2}{*}{81,82} \\
\hline & & & $\begin{array}{l}\text { Hasil tugas yang } \\
\text { diberikan }\end{array}$ & 16 & 72,73 & \\
\hline \multirow[b]{2}{*}{2} & \multirow[b]{2}{*}{$\begin{array}{l}\text { Tanggung } \\
\text { kelompok }\end{array}$} & \multirow[b]{2}{*}{ jawab } & $\begin{array}{l}\text { Menyelesaikan tugas } \\
\text { tepat waktu }\end{array}$ & 20 & 90,91 & \multirow[b]{2}{*}{84,09} \\
\hline & & & $\begin{array}{l}\text { Kelompok dapat } \\
\text { menyelesaikan } \\
\text { tugasnya dengan benar }\end{array}$ & 17 & 77,27 & \\
\hline
\end{tabular}




\begin{tabular}{|c|c|c|c|c|c|}
\hline \multirow[b]{2}{*}{3} & \multirow[b]{2}{*}{ Kerja Sama } & $\begin{array}{l}\text { Bekerja sama dalam } \\
\text { menyelesaikan tugas }\end{array}$ & 19 & 86,36 & \multirow[b]{2}{*}{86,36} \\
\hline & & $\begin{array}{l}\text { Mengemukakan } \\
\text { pendapat dalam } \\
\text { memecahkan masalah }\end{array}$ & 19 & 86,36 & \\
\hline \multirow[t]{2}{*}{4} & \multirow[t]{2}{*}{ Pembagian Tugas } & $\begin{array}{l}\text { Mendapatkan tugasnya } \\
\text { secara merata }\end{array}$ & 22 & 100 & \multirow[t]{2}{*}{93,18} \\
\hline & & Mengerjakan tugas & 19 & 86,36 & \\
\hline \multirow[t]{4}{*}{5} & \multirow[t]{2}{*}{ Kepemimpinan } & $\begin{array}{lr}\text { Mampu } & \text { mengajak } \\
\text { anggota } & \text { kelompoknya } \\
\text { kompak } & \\
\end{array}$ & 17 & 77,27 & \multirow[t]{2}{*}{81,82} \\
\hline & & $\begin{array}{l}\text { Mengarahkan anggota } \\
\text { kelompoknya }\end{array}$ & 19 & 86,36 & \\
\hline & $\begin{array}{l}\text { Rata-Rata } \\
\text { Keseluruhan }\end{array}$ & & & & 85,45 \\
\hline & Katagori & & & & $\begin{array}{l}\text { SangatA } \\
\text { ktif }\end{array}$ \\
\hline
\end{tabular}

Dari tabel tersebut terlihat rata-rata keaktifan siswa 85,15\%, apabila merujuk pada tabel keaktifan siswa dalam materi bangun ruang kubus, maka termasuk dalam kategori sangat aktif.

Keempat Refleksi. Hasil tes matematika bangun ruang balok pada Siklus II ini berhasil menuntaskan 19 siswa dari 22 siswa dengan rata-rata 86,36 dan persentase 86\%. Berarti masih ada 3 siswa yang belum mencapai ketuntasan belajarnya dikarenakan selama proses pembelajaran mereka masih mendapatkan nilai yang rendah di bawah KKM. Hal ini membuktikan bahwa model pembelajaran Kooperatif tipe Jigsaw dalam pembelajaran Matematika materi bangun ruang balok dapat meningkatkan kemampuan belajar siswa. Dari aktivitas pembelajaran dapat dilihat bahwa pada saat pembelajaran siswa sudah terlihat aktif dan tanggung jawab saat pembelajaran, siswa sudah berpartisipasi dalam mengemukakan pendapat dalam kelompok, siswa berbagi informasi antar kelompok dengan baik, dan siswa mendengarkan informasi yang disampaikan dengan baik.

\section{PEMBAHASAN}

Berdasarkan hasil pengamatan awal (pra siklus) diperoleh bahwa pada mata pelajaran Matematika materi bangun ruang dari 22 siswa kelas IV TP 2016/2017, masih terdapat banyak siswa yang mendapat nilai di bawah KKM, yaitu 13 anak 59\% dan hanya 9 anak 41\% yang dapat dianggap telah memenuhi standar KKM. Rendahnya prestasi belajar pada pra siklus dikarenakan guru belum menggunakan metode pembelajaran yang tepat. Setelah dilakukan tindakan pembelajaran Siklus I dengan menggunakan model pembelajaran kooperatif tipe Jigsaw, diperoleh hasil belajar siswa sebagai berikut : sebanyak 6 anak (27\%) yang masih dibawah standar KKM dan $16(73 \%)$ siswa yang sudah memenuhi standar KKM, rata-rata kelas mencapai 75,45 dengan persentase ketuntasn $73 \%$.

Tindakan pembelajaran Siklus II dalam pembelajaran Matematika materi bangun ruang dengan menggunakan model pembelajaran kooperatif tipe Jigsaw, 
diperoleh hasil belajar siswa sebagai berikut : sebanyak 3 anak (14\%) yang masih dibawah standar KKM dan 19 (86\%) siswa yang sudah memenuhi standar KKM, rata-rata kelas mencapai 86,36 dengan persentase ketuntasan $86 \%$.

Grafik presentasi prestasi belajar siswa kelas IV SD Negeri 46 Lubuklinggau pada mata Pelajaran Matematika materi bangun ruang pra siklus, siklus I, dan siklus II, ditunjukkan pada gambar berikut :

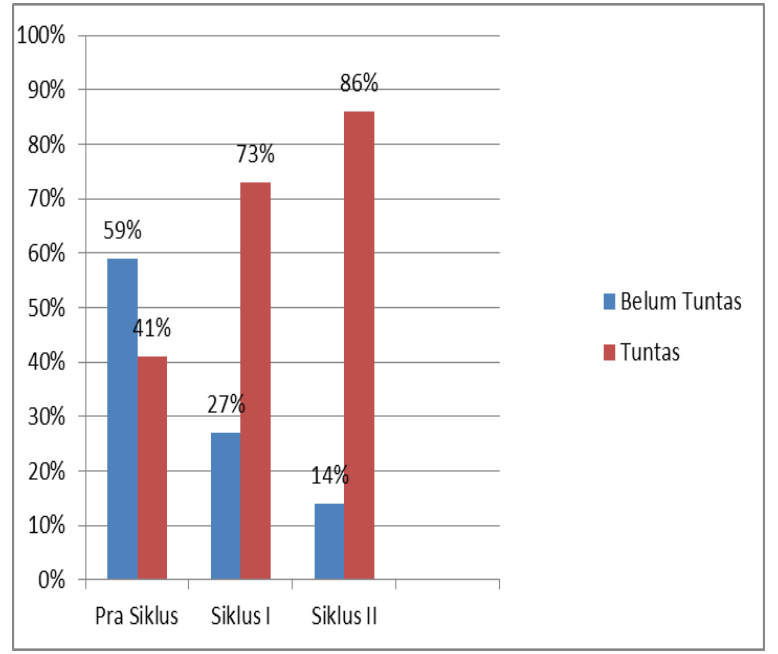

Grafik 1. Grafik Hasil Belajar Siswa

Dari grafik hasil belajar tersebut, dapat disimpulkan tes Matematika materi bangun ruang dengan menggunakan model pembelajaran Kooperatif tipe Jigsaw tiap siklusnya mengalami peningkatan. Dalam hal aktivitas belajar siswa banyak mengalami peningkatan yang signifikan yaitu siklus I 67,27\%, sedangkan siklus II $85,45 \%$. Peningkatan aktifitas belajar ini dikarenakan sudah menggunakan metode dan media pembelajaran yang sudah tepat. Grafik presentase aktivitas siswa kelas IV SD Negeri 46 Lubuklinggau mata pelajaran Matematika materi bangun ruang pada Siklus I dan Siklus II dapat dilihat pada gambar berikut :

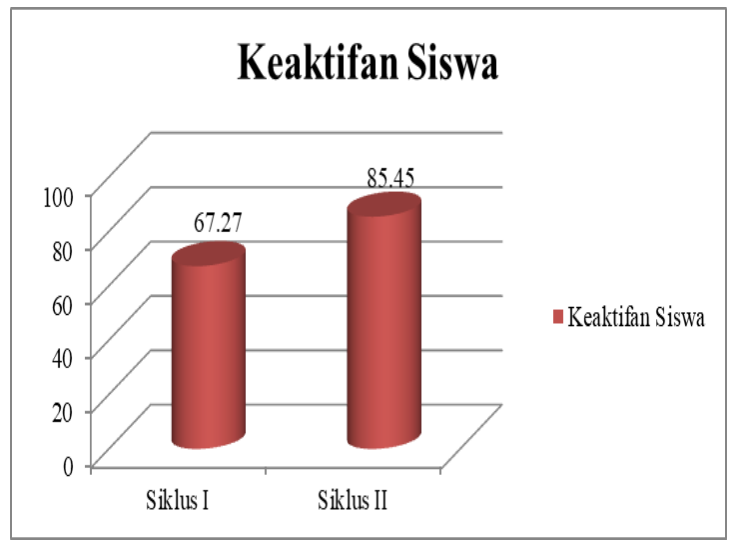

Grafik 2 Aktivitas Belajar Siswa 
Hasil refleksi terdapat hasil proses perbaikan permbelajaran dan hasil observasi yang dilakukan pengamat tercatat hal-hal sebagai berikut: Sebelum diadakan perbaikan pembelajaran pra siklus, Ilmu Pengetahuan Sosial tingkat kegairahan dan keberanian siswa tergolong rendah, siswa kurang aktif, ktifitas

pembelajaran masih di dominasih oleh guru. Namun setelah perbaikan pembelajaran siklus I, kegairahan dan keberanian siswa dalam pembelajaran meningkat menjadi 67,27 siswa terlihat aktif dan antusias dalam pembelajaran. Pada siklus II siswa aktif antusias semakin bertambah menjadi 85,45. Berdasarkan uraian tersebut dapat disimpulkan bahwa model pembelajaran Kooperatif tipe Jigsaw dapat meningkatkan hasil belajar siswa SD Negeri 46 Lubuklinggau pada pelajaran Matematika materi bangun ruang. Hal ini dapat dilihat dari nilai rata-rata siswa Siklus II yaitu 86,36 dengan persentase ketuntasan belajar yang mencapai $86 \%$. Selain itu nilai rata-rata hasil observasi aktifitas belajar siswa Siklus II mencapai 85,45 dalam katagori sangat aktif

\section{SIMPULAN}

Penelitian tindakan ini telah dikatakan tuntas dengan dibuktikannya peningkatan hasil belajar matematika model pembelajaran Kooperatif Tipe Jigsaw siswa kelas IV SD Negeri 46 Lubuklinggau semester ganjil tahun ajaran 2016/2017. Ketuntasan belajar meningkat dari Pra Siklus, siklus I, ke siklus II yaitu masingmasing 41\%, 73\%, dan $86 \%$. Pada siklus II ketuntasan belajar siswa secara klasikal telah tercapai dan mengalami peningkatan yang sangat baik. Selain itu nilai rata-rata hasil observasi aktifitas belajar siswa Siklus II mencapai 85,45 dalam kategori sangat aktif 


\section{DAFTAR PUSTAKA}

Arikunto, S. (2011). Dasar-dasar Evaluasi Pendidikan. Jakarta : Bumi Aksara .............(2002). Prosedur Penelitian. Jakarta : Rineka Cipta

Aqib. Z. (2006). Penelitian Tindakan Kelas. Bandung : 2006

Daryanto. (2011). Penelitian Tindakan Kelas dan Penelitian Tindakan Sekolah. Yogyakarta : Gava Media

Hamdani, N.,A \& Dody, H. (2008). Classroom Action Research. Bandung : Rahayasa Purwanto, N. (2001). Prinsip-prinsip dan Teknik Evaluasi Pengajaran. Bandung. Remaja Rosda Karya.

Slavin, R.,E . (2009). Cooperative Learning Teori: Riset dan Praktik. Bandung: Nusa Media. 